\title{
Nitrogen, Phosphorus and Minerals (Sodium, Potassium and Calcium) Contents of Some Algae's Species (Anabaena and Spirulina platensis)
}

\author{
Hanan M. Abobaker ${ }^{1}$, Hamida EL. Elsalhin ${ }^{1}$ and Hamad M. Adress Hasan ${ }^{2}$ \\ ${ }^{1}$ Botany Department, Faculty of Science, Omar El -Mukthar University, Libya \\ ${ }^{2}$ Chemistry Department, Faculty of Science, Omar El -Mukthar University, Libya \\ *Corresponding author
}

\begin{tabular}{l}
\hline Ke y w o r d s \\
Nitrogen, \\
Phosphorus and \\
Minerals, \\
Anabaena and \\
Spirulina platensis \\
\hline Article Info \\
\hline Accepted: \\
28 August 2016 \\
Available Online: \\
10 September 2016
\end{tabular}

A B S T R A C T

Some of minerals contents (sodium, potassium and calcium ) and addition to phosphorus and total nitrogen were determined in two different algae species which grow thing in laboratory in different solutions media. The algae species including (Anabaena and Spirulina platensis).The results showed different results of the investigated algae species for the studied metals, the data can be summarized as following: $\mathrm{Na}$ ( 73.3 and $225 \mathrm{ppm}$ ), $\mathrm{K}$ ( 12.3 and $9.5 \mathrm{ppm}$ ), $\mathrm{Ca}$ ( 55 and 115 ppm ), N ( 0.73 and $0.23 \mathrm{ppm}$ ) and P ( 3.95 and $5.807 \mathrm{ppm}$ ) for the (Anabaena and Spirulina platensis ) species, respectively. The study concluded that most of the selected ions were high accumulated in the Spirulina platensis algae specie comparing with Anabaena one.

\section{Introduction}

Algae comprise a complex and heterogeneous group of organisms characterized by their photosynthetic nature and their simple reproductive structures, According to their size, algae can be roughly divided into unicellular organisms, known as microalgae and multicellular organisms referred to as macro algae, Algae frequently live in extreme environments of light, salinity, and temperature, In order to adapt to these extreme conditions, most algae produce a high variety of secondary metabolites that often have potent biological activities, (Mattox et al., 1984). The importance of metal ions biological systems is now well established, It is well known that a number of metal ions are essential for biological systems, in that they are absolutely necessary for life processes (Ghallab, 2000), These elements are usually known as essential elements and includes $\mathrm{Na}, \mathrm{K}$, and $\mathrm{Ca}$, Storage implies concentration, and there must then be either a binding mode or an energized concentration gradient relative to the external solutions, Biological systems have selected certain elements for certain purposes and in so doing have reject others, The operation involved in concentrating an element, or rejecting it, will also involve steps using selective ion binding, The study of stability constants is therefore central to 
our understanding, The simplest store acts as a buffer when vital supplies are low, The nutrient (Nitrogen and phosphorous) store in itself is not much use unless it also is connected to a specific distribution and utilization system, Furthermore, nutrition requires a steady supply of required chemicals, and storage is then a valuable buffer of steady state use.

The functions of some metals in biological systems are diverse and complex, and often associated with a specific protein, Metals can function together with proteins in irreversible complexes (metallo proteins), and in reversible complexes (metal protein complexes), but there is also an intermediate class of reversible protein complexes, The first class of proteins are usually enzymes, the second class trigger biological response and act in transport, and the class may well be regulators, (El -Khair,1993). The aim of the current manuscript is to evaluate the bioaccumulation of sodium, potassium, calcium. nitrogen and phosphorus in two different types of algae's growthing in laboratory in different types of saline media.

\section{Materials and Methods}

The methods of preparation and the condition of grow thing the algae can be describing as following:

\section{Specific Medium of Anabaena}

\section{Isolation of Anabaena sp.}

The cultures were isolated and purified by repeated plating on solid $\mathrm{Chu} 10$ medium and colonies of different morphologies were identified according to morphological properties and pigment composition The microscopic structure was also observed, Table (1).
The nutrient medium was prepared by using one $\mathrm{ml}$ of each of the stock macronutrient solution and one $\mathrm{ml}$ of the micronutrient stock solution and making it up to one liter by distilled water. The final $\mathrm{pH}$ was then adjusted to 7.2. Potassium phosphate solution was autoclaved separately and then added aseptically to the sterilized medium to avoid phosphate precipitation. The composition of the macronutrient solution was given in Table (2).

Algal culture was grown in Erlenmeyer pyres-glass flasks capacity of $250 \mathrm{ml}$ containing $100 \mathrm{ml}$ culture medium. The flasks were grown under controlled light and temperature culture chamber. Culture experiments were conducted under a regime of $16 \mathrm{~h}$. light/ $8 \mathrm{~h}$. darkness.

\section{Production of purified algal biomass}

Pure culture was maintained by sub culturing in $250 \mathrm{ml}$ Erlenmeyer flasks containing $100 \mathrm{ml}$ of sterile Chu 10 medium (liquid) and incubated under florescent light (3000 lux) at a temperature of $25 \pm 1^{\circ} \mathrm{C}$. The culture was harvested by centrifugation (4000 rpm for 15 minutes) after 15 days of inoculation.

\section{Medium Spirulina platensis}

\section{Algal growth media}

Spirulina platensis was grown in Spirulina medium (Zarrouk 1966). It consists mainly as described in Table (3).

On the other side the micronutrient stock solution which used in growthing of Spirulina platensis was given in Table (4).

One $\mathrm{ml}$ from stock solution $\mathrm{b}+1.0 \mathrm{ml}$ from stock solution c were added to each $1000 \mathrm{ml}$ of solution a. *This salt was neglected in our 
work; this is because EDTA is a strong chelator for metal cations and it can sequester metal toxicity very much. Actually EDTA is used for detoxification of metal poisoning.

\section{Culture conditions}

Spirulina platensis was grown in conical Erlenmeyer pyrex-glass flasks (capacity 250 $\mathrm{ml}$ ). Each flask contained $50 \mathrm{ml}$ culture medium. The inoculated medium was adjusted to optical density above 0.1 unit in order to yield a linear growth curve with a lag phase. The cultures were grown under controlled laboratory conditions (temperature at $25^{\circ} \mathrm{C} \pm 1{ }^{\circ} \mathrm{C}$ and light at $80 \mathrm{~m}$ mol m $\mathrm{m}^{-2} \mathrm{~s}^{-1}$ ) in a controlled culture chamber. Temperature inside the growth chamber was kept as possible within $25^{\circ} \mathrm{C}$ through periodical ventilation.

Culture experiments were conducted under a regime of 16 hour light/ 8 hour dark. Each experimental culture flask was regularly swirled daily by hand to detach adhered algal cells from the walls of the flask. After each mixing, the flasks were returned back to a different position on the glass shelves inside the controlled chamber to remove any bias due to the illumination or temperature gradient on the shelves. The culture period lasted for 18 days. The number of replicates were three separate conical flasks for each measure.

\section{Harvesting of cultures for analyses}

At different periods of culturing which depend on the type of the tested metabolic compound, the cells of Spirulina platensis were harvested by centrifugation at $5000 \mathrm{r} \mathrm{p}$ $\mathrm{m}$ for $30 \mathrm{~min}$ using angle rotor centrifuge. The supernatants were discarded and the remaining pellets were used for the determination of the selected ions.

dry weight method

Algal samples from the different salt concentrations $(10 \mathrm{ml})$ were filtered under vacuum through $0.45 \mu \mathrm{m}$ filter membrane and washed several times with distilled water. Then, algal cells were dried at $100^{\circ} \mathrm{C}$ for $30 \mathrm{~min}$ and weighed (Abd El-Baky et al., 2003).

\section{Elemental analysis}

The sodium,calcium and magnesium contents were measured by Flamphotometer (Type JENWAY ). The phosphorus levels were determined according to molybedate and vanadate, while the nitrogen contents were measured by spectrophotometric method using Nesler reagent.

\section{Results and Discussion}

The contents of the selected minerals were given in Table (5). The data showed that the contents were fluctuated as following: $\mathrm{Na}$ (73.3 and $225 \mathrm{ppm}), \mathrm{K}$ (12.3 and 9.5 ppm), $\mathrm{Ca}$ (55 and $115 \mathrm{ppm}), \mathrm{N}$ (0.73 and $0.23 \mathrm{ppm}$ ) and $\mathrm{P}$ (3.95 and $5.807 \mathrm{ppm}$ ) for the (Anabaena and Spirulina platensis) species, respectively.

Table.1 The saline structure of media according to (Chu 10 )

\begin{tabular}{|c|c|c|c|}
\hline Salts & $\mathrm{gl}^{-1}$ & Salts & $\mathrm{gl}^{-1}$ \\
\hline $\mathrm{Ca}\left(\mathrm{NO}_{3}\right)_{2}$ & 0.04 & $\mathrm{Na}_{2} \mathrm{CO}_{3}$ & 0.02 \\
\hline $\mathrm{K}_{2} \mathrm{HPO}_{4}$ & 0.01 & $\mathrm{Na}_{2} \mathrm{SiO}_{3} .5 \mathrm{H}_{2} \mathrm{O}$ & 0.025 \\
\hline $\mathrm{MgSO}_{4} \cdot 7 \mathrm{H}_{2} \mathrm{O}$ & 0.025 & $\mathrm{FeCl}_{3}$ & 0.0008 \\
\hline
\end{tabular}


Table.2 Composition of the macronutrient solution

\begin{tabular}{|l|l|l|l|}
\hline Salts & $\mathrm{gl}^{-1}$ & Salts & $\mathrm{gl}^{-1}$ \\
\hline $\mathrm{NaNO}_{3}$ & 1.5 & Ferric ammonium citrate & 0.006 \\
\hline $\mathrm{K}_{2} \mathrm{HPO}_{4}$ & 0.04 & EDTA (disodium-salt) & 0.001 \\
\hline $\mathrm{MgSO}_{4} \cdot 7 \mathrm{H}_{2} \mathrm{O}$ & 0.075 & $\mathrm{Na}_{2} \mathrm{CO}_{3}$ & 0.02 \\
\hline $\mathrm{CaCl}_{2} \cdot 2 \mathrm{H}_{2} \mathrm{O}$ & 0.036 & $*$ Micronutrient solution & $1 \mathrm{ml}$ \\
\hline \hline Citric acid & 0.006 & Distilled water & One liter \\
\hline
\end{tabular}

Table.3 The macronutrients solution of Spirulina platensis.

\begin{tabular}{|c|c|}
\hline Macronutrients (Solution a) & Quantity (g.) \\
\hline $1-\mathrm{NaCl}$ & 1.0 \\
\hline 2- $\mathrm{MgSO}_{4} \cdot 7 \mathrm{H}_{2} \mathrm{O}$ & 0.2 \\
\hline 3- $\mathrm{CaCl}_{2} \cdot 2 \mathrm{H}_{2} \mathrm{O}$ & 0.04 \\
\hline 4- $\mathrm{FeSO}_{4} \cdot 7 \mathrm{H}_{2} \mathrm{O}$ & 0.01 \\
\hline 5- $\mathrm{Na}_{-} \mathrm{EDTA}^{*}$ & 0.08 \\
\hline 6- $\mathrm{K}_{2} \mathrm{HPO}_{4}$ & 0.5 \\
\hline $7-\mathrm{NaNO}_{3}$ & 2.5 \\
\hline $8-\mathrm{K}_{2} \mathrm{SO}_{4}$ & 1.0 \\
\hline 9- $\mathrm{NaHCO}_{3}$ & 16.8 \\
\hline $10-\mathrm{Distilled} \mathrm{H}_{2} \mathrm{O}$ & $1000 \mathrm{ml}$ \\
\hline
\end{tabular}

Table.4 Micronutrient stock solution contents

\begin{tabular}{|c|c|c|c|}
\hline \multicolumn{4}{|c|}{ Micronutrient stock solution } \\
\hline \multicolumn{2}{|l|}{ Stock solution b } & \multicolumn{2}{|c|}{ Stock solution c } \\
\hline $1-\mathrm{NH}_{4} \mathrm{NO}_{3}$ & $0.023 \mathrm{~g}$ & $1-\mathrm{H}_{3} \mathrm{BO}_{3}$ & $2.820 \mathrm{~g}$ \\
\hline $2-\mathrm{K}_{2} \mathrm{Cr}_{2}\left(\mathrm{SO}_{4}\right)_{2} .27 \mathrm{H}_{2} \mathrm{O}$ & $0.096 \mathrm{~g}$ & 2- $\mathrm{MnCl}_{2} \cdot 4 \mathrm{H}_{2} \mathrm{O}$ & $1.810 \mathrm{~g}$ \\
\hline 3- $\mathrm{NiSO}_{4} \cdot 7 \mathrm{H}_{2} \mathrm{O}$ & $0.044 \mathrm{~g}$ & 3- $\mathrm{ZnSO}_{4} \cdot 7 \mathrm{H}_{2} \mathrm{O}$ & $0.222 \mathrm{~g}$ \\
\hline 4- $\mathrm{Na}_{2} \mathrm{SO}_{4} \cdot 7 \mathrm{H}_{2} \mathrm{O}$ & $0.018 \mathrm{~g}$ & 4- $\mathrm{CuSO}_{4} \cdot 5 \mathrm{H}_{2} \mathrm{O}$ & $0.077 \mathrm{~g}$ \\
\hline 5- Ti $\left(\mathrm{SO}_{4}\right)_{3}$ & $0.040 \mathrm{~g}$ & $5-\mathrm{MoO}_{3}$ & $0.015 \mathrm{~g}$ \\
\hline 6- $\mathrm{Co}(\mathrm{NO})_{2} \cdot 6 \mathrm{H}_{2} \mathrm{O}$ & $0.044 \mathrm{~g}$ & 6- Distilled $\mathrm{H}_{2} \mathrm{O}$ & $1000 \mathrm{ml}$ \\
\hline 7- Distilled $\mathrm{H}_{2} \mathrm{O}$ & $1000 \mathrm{ml}$ & & \\
\hline
\end{tabular}


Table.5 The contents of the elements in the both studied algae species.

\begin{tabular}{|c|c|c|c|}
\hline \multicolumn{3}{|c|}{ Algae Species } \\
\hline Anabaena Algae & \multicolumn{2}{c|}{ Spirulina platensis Algae } \\
\hline Sodium & $7.33 \mathrm{ppm}$ & Sodium & $225 \mathrm{ppm}$ \\
\hline Potassium & $12.33 \mathrm{ppm}$ & Potassium & $9.5 \mathrm{ppm}$ \\
\hline Calcium & $55 \mathrm{ppm}$ & Calcium & $115 \mathrm{ppm}$ \\
\hline Phosphorus & $3.58 \mathrm{ppm}$ & Phosphorus & $5.80 \mathrm{ppm}$ \\
\hline Nitrogen & $\mathbf{0 . 3 7} \mathrm{ppm}$ & Nitrogen & $0.23 \mathrm{ppm}$ \\
\hline
\end{tabular}

Fig.1 The percentage $(\%)$ of the studied elements of Anabaena species

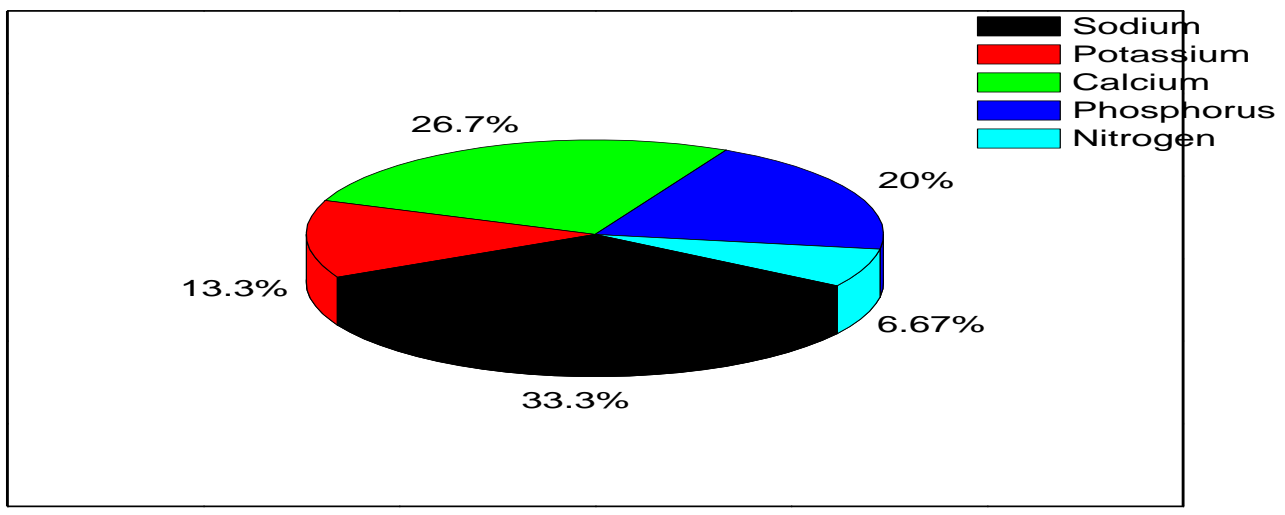

Fig.2 The percentage (\%) of the studied elements of Spirulina platensis Algae species

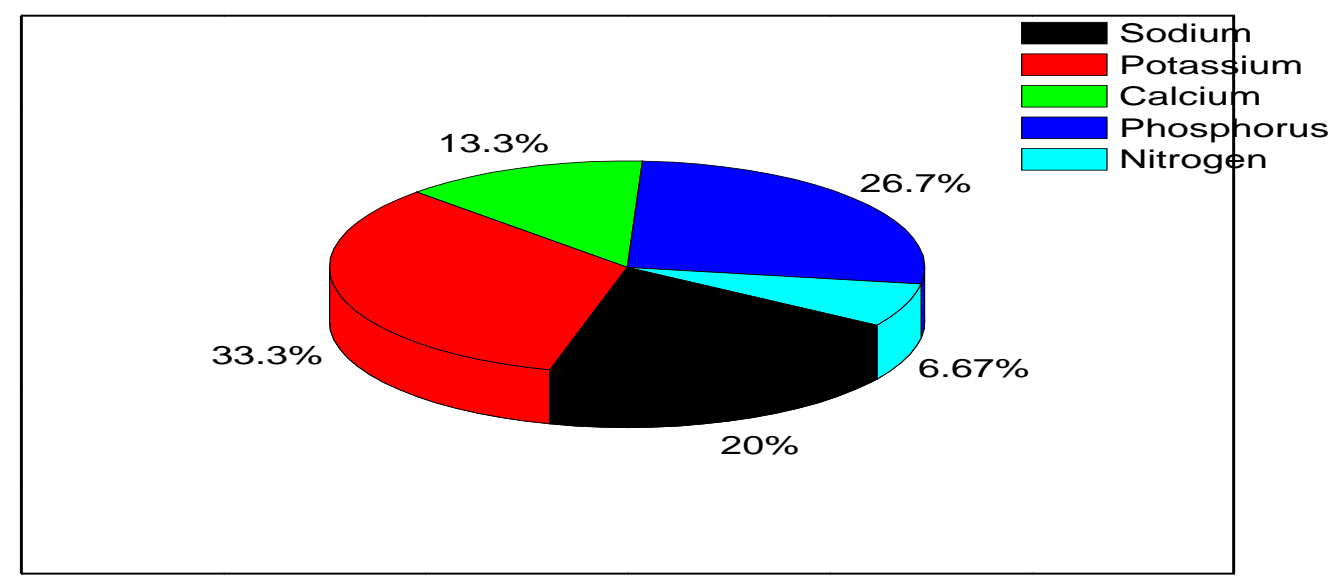

The results indicated that there is relative variations in some contents of the studied elements especially for sodium and calcium
On the other hand no different values were recorded for the other studied elements, the different mainly due to the stock solution of 
the algae growth. The bioaccumulation of studied metals may be concerning with the nature of the physiological structure of the algae species.

In conclusion, from the data which recorded in this investigation we can say that the contents of the solutions are affecting on the accumulation of the elements in the studied species, the study highly recommend to study the other factors which may affecting on the distribution the metals as Temperature or $\mathrm{P}^{\mathbf{H}}$.

\section{References}

Abd El-Baky, H.H. 2003. Over production of phycocyanin pigments I blue green alga Spirulina sp. and its inhibitory effect on growth of Ehrlich Ascites Carcinoma Cells. J. Med. Sci., 3: 314324.

Chu, S.P. 1942. The influence of the mineral composition of the medium on the growth of planktonic algae. 1 method of culture media. J. Ecol., 30: 284-
325.

El -Khaier, E.M. 1993. Chemical studies on the Mediterranean coastal waters in the front of the Rosetta mouth of the Nile, M.Sc., thesis, Faculty of science, Alexandria university.

Ghallab, M.H.M. 2000. Some physical and chemical changes on River Nile downstream of Delta at El-Rahawy drain MSc. Thesis, Faculty of Science. Ain Shams University. Cairo, Egypt, 230pp.

Mattox, K.R. and K.D. Stewart. 1984. Classification of the green algae: a concept based on comparative cytology. In systematics of the Green Algae, ed. D. E. G. irvine and D. M. John, pp 2972. Systematics Association special vol. no. 27. Academic Press, London.

Zarrouk, C. 1966. "Contribution a l'Etude d'une Cyanophycre sur la Croissance de la Photosynthrse de Spirulina maxima". Stech et Gardner (ed.), Geitler, These, Paris.

\section{How to cite this article:}

Hanan M. Abobaker, Hamida EL. Elsalhin and Hamad M. Adress Hasan. 2016. Nitrogen, Phosphorus and Minerals (Sodium, Potassium and Calcium) Contents of Some Algae's Species (Anabaena and Spirulina platensis). Int.J.Curr.Microbiol.App.Sci. 5(11): 836-841. doi: http://dx.doi.org/10.20546/ijcmas.2016.511.095 